\title{
Scevole de Ste Marthe of France (1536-1623) and The Paedotrophia
}

\author{
P M Dunn
}

Scevole de Ste Marthe was born in Loudun, France, in 1536. He studied law, first at the University of Paris, and then at the University of Poitiers where he settled, married, and successively became Mayor, Governor, and then President of the District. ${ }^{1}$ Besides being a lawyer, he was also a fine poet. Although not a medical man, his most famous work, The Paedotrophia, was a Latin poem in three books on pregnancy, childbirth, and the care of infants. It was first published in 1584 and was reprinted many times over the next two centuries. Henry III of France, to whom the poem was dedicated, requested him to translate it into French; it was also translated into English, first in 1710, and then again in 1797 by Dr Tyler, a medical practitioner in Forfarshire. It is from this second translation that the extracts that follow were taken. ${ }^{2}$

Scevole de Ste Marthe first developed an interest in the care of infants when two of his own children became seriously ill and died of smallpox. He describes the occasion poignantly:

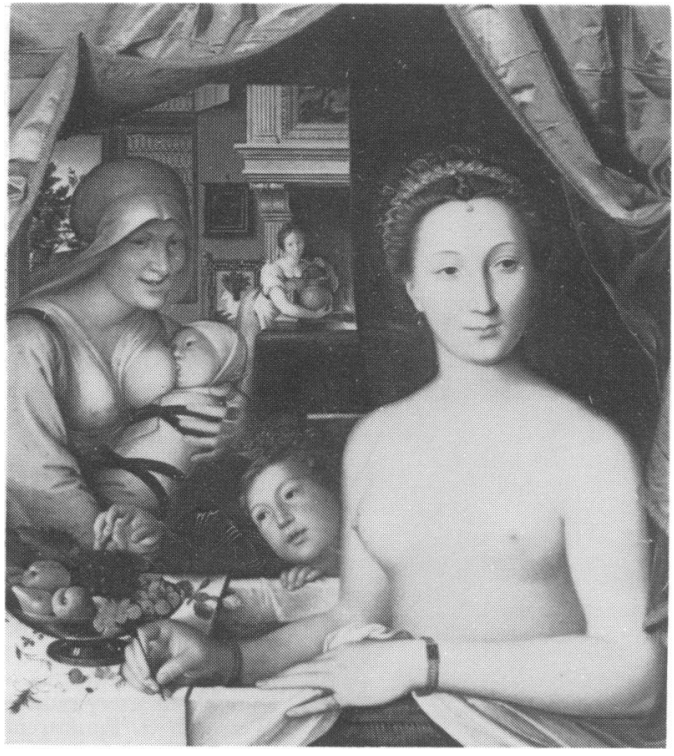

Diane de Poitiers (1571) with her infant and wet nurse.

'When they, by violence, bring from within A load of pustules on th' inflaming skin, That, with unnumber'd wounds, deform the face, And ev'ry issue of the soul oppress.

By this (Oh! sad remembrance, fatal tale!)

To me two beauteous infants lately fell:

Four summers o'er my lovely Charles had run,

And thrice Diana saw the annual sun,

But, ere the next, from me, and from my spouse

Were snatch'd the double honours of our house.

Ye mighty Gods! if love for man remain,

And all a Poet's pray'rs be not in vain,

Save the delightful pledges of our bed,

That yet survive, from these dire ills that shed

Destruction round; avert th' infectious woe,

Nor wound our peace by a succeeding blow'.

After this experience, as his biographer Gabriel Michel wrote in 1629 , 'he was not sparing of the experience and care of the best physicians; he applied himself likewise to search curiously the natures and constitutions of infants ... His researches (were) so successful that he cured his young son by remedies of his own prescribing after he was given over by the physicians. Being then entreated by his friends to communicate such curious discoveries to the public he comprehended them in this poem'. It brought him fame. The Paedotrophia was studied throughout the universities of Europe for the next 200 years with the same veneration as was accorded to works from classical times. Not only was it the first post-renaissance tract on infant care but it abounded with sound commonsense and practical advice:
Correspondence to: Department of Child Health, Southmead Hospital Southmead Road,
University of Bristol, Southmead Hospital P M Dunn

Bristol BS10 5NB. 
'A Sage declar'd, and with the speech I'm pleas'd, No Mother, should from nursing be releas'd, But freely give what oft she keeps with pain, And let her Child the snowy fountains drain . . .'

'But when the child within the craddle lies, Demanding aid with tears, and melting cries . . '

'To sooth his soft complaints, the mother fly, And bring the tempting breast before his eye, Advance the nipple to his op'ning lip,

And give him still th'ambrosial juice to sip,

Then, strange to tell, new pleasure fill his mind,

And calm his griefs, and mingle with the wind? . . '

'Spontaneous still the grateful liquor glides, And still the child sucks in the flowing tides, Attempts with hands and mouth the breast to seize, And drains the kindred juice, and lies at ease ...'

There is useful advice on the technique of breast feeding and on weaning:

'But, at the first, while small and weak his jaws, Balk not his hopes, when he the nipple draws; But squeeze your breast with gentle pressure still, And bring him close, and give the child his fill

Yet let him not, too much, the fountains drain; Sometimes indulge the feast, sometimes restrain;

Just at his mouth the nipple take away,

And raise his hunger by a short delay . . .'

'And I, for suckling, no fix'd hour prescribe;

This Nature teaches best the nursing tribe:

Let her your mistress be; and when, with cries

The hungry child demands his due supplies,

Forbear not you the wish'd relief to bring,

But, for his use, unlock the sacred spring;

Nor then be loth your snowy breast to bare,

That he may suck, and streaming fragrance share. . .'

'But, in short time, the growing babe will need

Not on th' ambrosial juice alone to feed.

When twice four times the moon has fill'd her orb,

And shooting teeth the swelling gums disturb,

Restrain the flowing feast ...

'When now you change, and give but half the breast,

Food, most resembling milk, is still the best:

Nor is it good too suddenly to use

Viands, quite diff rent from the kindred juice,

Unless you know their nature to correct,

And form the medium his desires expect'

Ste Marthe attached great importance to avoiding both chilling and over heating of the newborn infant; in particular he warned against bathing in cold water.

'Remember too, that only, by degrees,

His tender skin endures the cooling breeze:

Expose not, recent from the womb, the child,

Except to gentle heat, and seasons mild;

Lest ills succeed, lest penetrating cold

Benumb his limbs, and of his joints take hold . . .'

'A craddle soft and well-prepar'd he needs;

There lay him down, and, while he rests, take care,

You neither make too cold nor hot the air:

From cold will coughs and rheumatisms spring,
And heat indulg'd exhausted spirits bring.

Extremes in ev'ry case are wrong, and must;

Still in a medium you more safely trust:

But this few female minds have known to use,

And ev'ry liberty are apt t' abuse.

Misguided fondness makes our nurses err

By heating infants, and excluding air,

Hence are their limbs relax'd, their spirits weak;

Hence oft the thread of life itself will break;

And thus the widow'd mother vainly mourn

Her blested hopes, that can no more return'.

The Paedotrophia contains plenty of advice, much of it sound, on such matters as the care of the umbilical cord, tongue tie, teething, and bowel problems. There is also advice to the mother on the antenatal care of her child, and on the conduct of labour and delivery:

'Then, when the nine revolving moons are run, When now the long-expected hour comes on,

Invoke Lucina's aid, with potent voice,

And let a skilful midwife be your choice;

That death, nor danger, may the birth attend,

But former pains in coming pleasures end.

Let her, with hand and voice, assist your throes,

With oft-repeated touches soothe your woes . . .

Then, whether on a bed your limbs repose,

Or in a chair you wait the coming throes,

(For either way is good), be not dismay'd,

Nor of the fiercest pain at all afraid;

Let not your strength of mind to these give way,

But conquer still, less you the birth delay.

If, in your limbs, such vigour yet remains,

Stand up, for standing will assist your pains . . .

But cease not you, your weary'd limbs to spread,

To bend your knees, or on the chair, or bed;

And grasp some strong support with all your pow'r,

T'increase your efforts in that painful hour'.

'But now the helpless infant leaves the womb,

That, nine long moons, had been his living tomb;

And, as the sign of our first mother's sins,

With cries, and soft complaints, his life begins.

Then you, to whom the tender. cares belong,

Or maids, or nurses, round the child-bed throng,

Make haste; and since both wife and infant claim

An equal succour, let them find the same.

While, for the wearied mother, some prepare

The bed, let others make the child their care,

In cloths well-warm'd involve his tender limbs,

And, for the bath, infuse the tepid streams

In proper vessels; some the cradle make,

And all the house in joyful toil partake'.

Scevole de Ste Marthe lived to be 87 . He died in 1623 and was buried in the Cathedral at Loudun, his birthplace. His epitaph described him as 'Pater Patriae'.

1 Still GF. The history of paediatrics. Oxford: Oxford University Press, 1931.

2 Ste Marthe $\mathrm{S}$ de. Paedotrophia or the art of nursing and rearing children. 1584. Translated from the Latin by $H W$ Tyler. London: Nichols, 1797. 